\title{
An In-Depth Qualitative Analysis of Situated Learning Instruction in Situation Awareness for Military English Course
}

\author{
Hsiu-Yu Yao ${ }^{1}$, Yu-Tang Hung ${ }^{2}$ \\ ROC Air Force Academy, Taiwan (R.O.C.) $)^{1}$ \\ National University of Tainan, Taiwan (R.O.C.) ${ }^{2}$ \\ Email Correspondence: tonycafa@hotmail.com
}

\section{Background:}

Abstract

While situated learning (SL) instruction has been adopted for educational purposes in many fields, an SL environment for military English has not been considered. Situation awareness (SA) is an important theme in the military English course, SL instruction can be a suitable method to enhance cadets' learning performance in SA operation. This study investigated the SA concept formation and operation as the effects of conducting SL instruction.

\section{Methodology:}

A film acted as an authentic military context, which sixteen cadets in Taiwan, R.O.C. accessed to perform SA. On the basis of Blooms' six cognition levels, the researchers gave an in-depth qualitative analysis over their learning performance of SA. The research tools include worksheets, English role-plays, and concept maps. Worksheets were designed to observe their SA concept formation in four film situations during Endsley's three steps of SA: perception, comprehension, and projection. English role plays were employed to judge whether they actively operated SA. And finally concept maps were used to see if they formed new SA concepts.

\section{Findings:}

The participants showed their critical thinking in SA concepts and even created another possible SA operation. When doing concept maps, they can combine previous learning in other military courses, Endsley's theories, and examples from the film and thus acquire new SA concepts.

\section{Conclusion:}

Through an in-depth qualitative analysis, the research results indicate that the SL instruction is effective in helping the cadets operate SA in the battlefield situations since they have reached each level of Bloom's educational objectives.

Keywords: situation awareness; military English; situated learning instruction; Taxonomy of educational objectives

\begin{tabular}{|c|c|c|}
\hline DOI & : & http//dx.doi.org/10.24903/sj.v6i1.671 \\
\hline Received & : & January 2021 \\
\hline Accepted & : & March 2021 \\
\hline Published & : & April 2021 \\
\hline Copyright Notice & $:$ & $\begin{array}{l}\text { Authors retain copyright and grant the journal right of first publication with the } \\
\text { work simultaneously licensed under a Creative Commons Attribution 4.0 } \\
\text { International License that allows others to share the work with an acknowledgement of } \\
\text { the work's authorship and initial publication in this journal. } \\
\text { (C) () () }\end{array}$ \\
\hline
\end{tabular}




\section{INTRODUCTION}

English education always occupies a significant position in cadets' military careers. As learning advanced military technology, training methods, knowledge of weaponry, intelligence exchange, logistics and maintenance reinforces national defense policies and even benefits battling results, to cooperate with American military affairs depend on good English ability. As the US government only certifies the English training materials ALC (American Language Course) and ECL (English Comprehension Level Tests) as the instrument to assess the military personnel's English proficiency in Taiwan, the cadets are required to attend an annual test on ALCPT (American Language Course Placement Test). While the test result around 75 to 80 points is the criterion for admission to training abroad, the cadets in the school under study only got an average of 50 points in the recent 5 years. The poor performance is due to their exhaustion by exercises, tasks, and physical training programs; the instructor-centered and lecture-oriented programs become dull for them. It is urgent to set learning in real military situation so that they can learn in practice. The military English course is to teach military concepts in English, so the present syllabus material ALC contains topics such as firearms, the science of flying, military authority, radar and sonar, explosive ordnance disposal, and many others. Without doubt, cadets have to prepare themselves for fighting in the battlefield; the military concept like situation awareness (SA) is critical and should be learned through situated learning (SL). However, since cadets rarely confront real military situations, one way to expose them to the authentic military situation where military terms and concepts are used is via films.

The cadets are guided to operate SA in four situations concerning killing people in the battlefield in the film Fury. SA contains three levels: to perceive crucial factors in the surrounding, to understand what the factors signify, and to predict what will occur with the system in the near future (Endsley, 1988). Although SL focuses on "the very process of participation in the immediate situation" (Fenwick, 2001). (WePengiran et al., 2018) claims it would advance learning if combined with learning through knowledge acquisition. Accordingly, this study emphasizes both SA knowledge acquisition and participation in the military situation. The military English course evaluates the cadets' learning performance of SA in light of Bloom's six levels of cognitive learning objectives: knowledge, comprehension, application, analysis, synthesis, and evaluation (Bloom, 1956). Probing into the topic of SA for the military English course, the teachers enable the cadets to learn military English terms and dialogues. Yet, as SA concept and application is treated as a topic of military English subjects, this study highlights it rather than accessing the cadets' military English learning efficacy. 
The purpose of the study is to observe how much new SA knowledge was acquired by calculating the new nodes on the concept maps and whether Bloom's teaching objectives were achieved by conducting an in-depth qualitative analysis over the reasons underlying the cadets' SA operation in the worksheets and role plays. Hence, three research questions are addressed: 1) By worksheets and concept maps, do the cadets learn the concept of Endsley's SA before deciding to kill certain people in the battlefield? 2) By role plays on SA, do the cadets learn the operation of Endsley's SA in practice before deciding to kill certain people in the battlefield? 3) Does the SL instruction in SA help the cadets achieve Bloom's taxonomy of cognitive learning objectives in SA learning?

It is (Brown et al., 1989) presented the viewpoint of "situated cognition" and "situation learning" by putting learning under cultural context. For Contu \& Willmott (2003) the context ranges from a classroom to specific work practices. Thus, the first factor of SL lies in learning in an authentic situation. Second, new practitioners need social interaction and collaboration within the "community of practice" (Wenger, 1999). Lave \& Wenger (1991) called this unintentional process "legitimate peripheral participation". Learning is thus scaffolded with this apprenticeship, as (Huang et al., 2011, p. 1201) stated, "through modeling, coaching and prompting for learner reflection". Third, according to Lave \& Wenger (1991), active participation in "a situated activity" (Greeno, 1993, p. 100) of social communities is critical. Through the process of sharing information and experiences with the group, members learn from each other and develop personally and professionally (Lave \& Wenger, 1991). Lastly, learning is a process of constantly forming significance for knowledge through active searching, operating and figuring out the relation and structure within knowledge. Lave and Wenger named the process "learning in practice".

SL has been adopted in many fields such as language learning (Comas-Quinn et al., 2009; Efe et al., 2011; Kyratzis \& Johnson, 2017; Shih \& Yang, 2008; Uz Bilgin, 2016; Yang, 2011) educational technology course (Huang et al., 2011; Wang et al., 2020), distance education information literacy course (Catalano, 2015), cognitive apprenticeship in management education (Matsuo \& Tsukube, 2020) and instructional strategies for students with special needs (Utley, 2006). Most existing studies discussed the use of certain SL approaches; however, little research has focused on implementing SL in military education except a study on an innovative academic-practice partnership in military (Comas-Quinn et al., 2009; Efe et al., 2011; Kyratzis \& Johnson, 2017; Uz Bilgin, 2016; Yang, 2011) nurses training (Barr et al., 2019). SL for military English has not yet been implemented. This led to our 
attempt at designing an SL environment in a military English course, which would allow us to simultaneously examine the cognition and application of SA concept.

The term of situation awareness originates from the domain of the military pilot; yet making an effective decision lies in SA in almost every field of effort. It includes three levels: 1) Perception of the elements in the environment: The operator is required to perceive the status, attributes, and dynamics of relevant elements in the environment (Endsley, 2001). 2) Comprehension of the current situation: The operator has to comprehend the situation in accordance with his goal by synthesizing the incoherent elements in the environment perceived in Level 1 (Endsley, 2001). 3) Projection of future status: The operator is able to predict what the elements in the environment will function in the (near) future after obtaining the "knowledge of the status and dynamics of the elements and a comprehension of the situation" (Endsley, 2001, p.5).

The cadets' learning performance of SA concept formation and application is evaluated via Bloom's taxonomy of educational objectives. Thus, a comparison between Bloom's taxonomy and Endsley's dynamics of SA is made (see Figure 1).

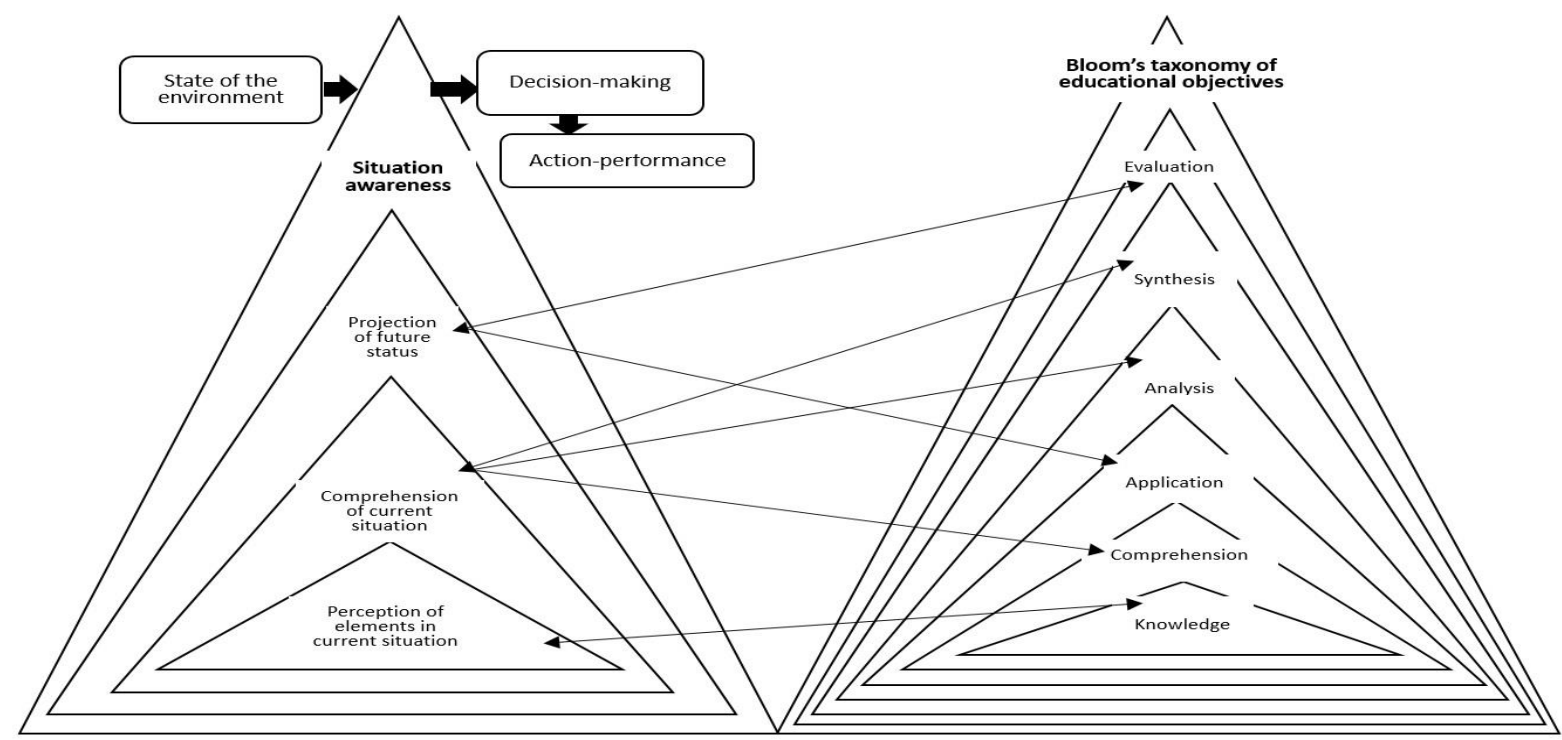

Figure 1 A Model of Bloom's Taxonomy for Dynamics of SA

The researchers find that Bloom's level 1 regarding "knowledge" copes with level 1 of SA concerning "perception" of elements in current situation. Bloom's level 2 on "comprehension", level 4 on "analysis", and level 5 on "synthesis" offer the requisite mental work to achieve Endsley's level 2 on "comprehension of the current situation". Bloom's level 3 on "application" and the uppermost level on "evaluation" elucidate how SA's final level on "projection" of future status could be attained. 


\section{METHODOLOGY}

In the military English course, the cadets are guided to learn the knowledge of SA in operation through the situated learning instruction. Combining Bloom's taxonomy and Endsley's dynamics of SA, the researchers' study if the cadets reach the different levels of educational objectives in SA learning in the context of the military situation.

\subsection{Instructional Design}

Following the four factors of SL, this research used a film as an authentic military context; the teachers and the characters in the film served as guiders/old timers, transmitting knowledge and skills of SA in terms of apprenticeship. Through "legitimate peripheral participation", the cadets shared information and actively joined in socio-cultural communities (Lave \& Wenger, 1991, p. 52) of SA. They went through the process of knowledge construction by not only acquiring and comprehending knowledge of SA but also applying it by analyzing, synthesizing, and evaluating the situations with Bloom's cognitive levels.

By watching the military movie, the cadets immediately entered four combat situations where they had to develop SA. The film depicts the battles between the US and Germany in the World War Two where an American rookie, Norman, confronts the hard decision of killing people with special identification under a US Army Staff Sergeant's leadership. The sergeant's three crewmen know the battlefield situations well and serve as the old-timers/instructors for Norman. The situations refer to killing the boy scout, the corpses, the prisoner of war, and the heavy odds. In former classes, the cadets had given a vocabulary presentation by locating sixty ME terms in the four situations, classifying them into one of the four categories (weaponry, logistics, ranks and units, as well as orders), illustrating them by giving correlated examples and information, showing the context and usage of the terms, and finally interacting with peers by $\mathrm{Q}$ and $\mathrm{A}$ on the terms. They had also taken two tests on the ME vocabulary. For other teaching activities on SA concepts in this study, the cadets reviewed the ME terms first.

Then, the teachers guided discussion about the situations and introduced Endsley's theory of SA. To provoke learning SA in practice, the cadets were required to use the ME terms to write worksheets. When actively developing the in-practice knowledge, they would turn into members of the SA community. Then they shared worksheets and put other classmates' views into consideration, which referred to Endsley's theory of SA, humanity concern, the Law of Armed Conflict (LOAC), and five requirements for national defense, i.e., human resources, intelligence, combat and planning, logistics, and communication.

Renewing SA knowledge after the teachers' instruction and discussion, they made different decisions to kill the people or not in the four situations by going through the SA 
process. The review of the post-worksheet is another key point for them to decide whether they should follow the old timer's practice or develop their own when giving an English role-play on SA operation, which signifies exactly learning in practice.

\subsection{Research Design}

The research participants are sixteen cadets in Taiwan, R.O.C.. As they experienced the same military school life and education, the study observes their difference in attitude toward fighting in the battlefield. They were coded from A to P for the convenience of an in-depth qualitative analysis over their viewpoints on the worksheets. Before the class, they had a preworksheet and pre-concept map on SA individually so that their naïve understanding of SA was revealed. After the discussion about the situations in the movie and instruction in SA, a post-worksheet served to provoke critical thinking. The research process is shown in Figure 2.

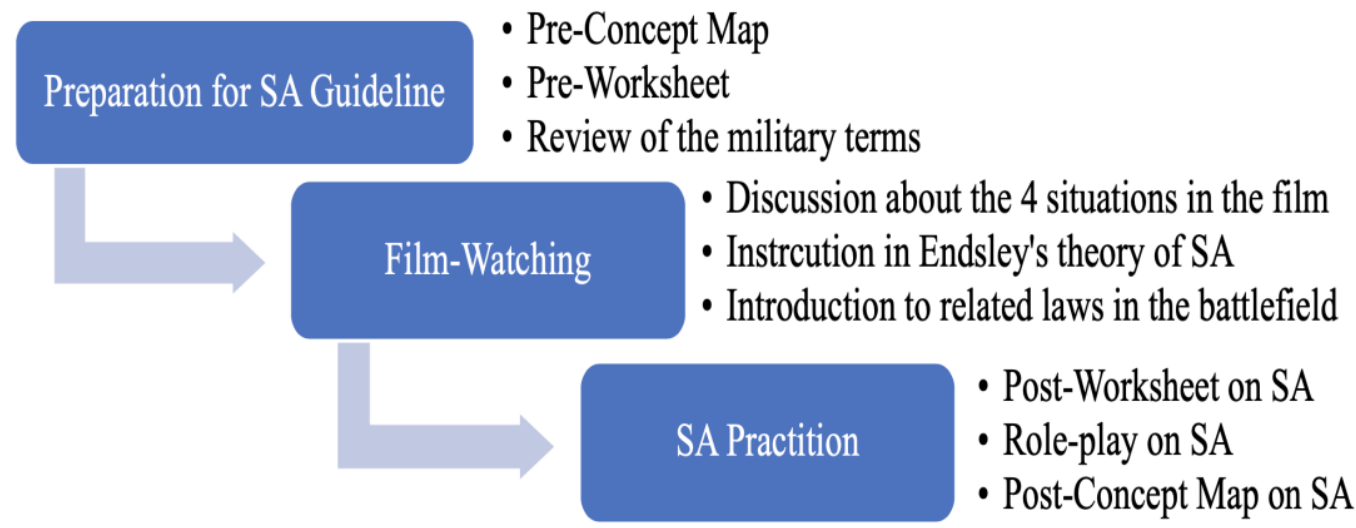

Figure 2 Instructional and Research Process

To assess the cadets' SA concepts for ME learning, the researchers used tools such as worksheets, English role-plays, and concept maps. The first research tool, worksheets on SA, contains four combat situations in the film mentioned before and three aspects originating from Endsley's theories: perception, comprehension, and projection. The questions were designed like those in Table 1.

Table 1. Questions for Worksheets on SA

\begin{tabular}{|c|c|c|c|}
\hline Situations & $\begin{array}{l}\text { Perception level } \\
\text { of SA } \\
\end{array}$ & $\begin{array}{c}\text { Comprehension level } \\
\text { of SA }\end{array}$ & $\begin{array}{c}\text { Projection level } \\
\text { of SA }\end{array}$ \\
\hline $\begin{array}{l}\text { A. When your tank } \\
\text { convoy was passing } \\
\text { through a bush, you } \\
\text { glanced a ten to fifteen- } \\
\text { year-old kid in the } \\
\text { enemy's uniform, }\end{array}$ & $\begin{array}{l}\text { 1. did you perceive } \\
\text { that kids were forced } \\
\text { to join up? What is } \\
\text { your perception } \\
\text { based on? }\end{array}$ & $\begin{array}{l}\text { 2. would you regard } \\
\text { the kid as an enemy? } \\
\text { How do you } \\
\text { comprehend the } \\
\text { situation? }\end{array}$ & $\begin{array}{l}\text { 3. would you shoot the } \\
\text { kid without } \\
\text { hesitation? What do } \\
\text { you project the } \\
\text { decision would result } \\
\text { in? }\end{array}$ \\
\hline
\end{tabular}




\begin{tabular}{|c|c|c|c|}
\hline Situations & $\begin{array}{l}\text { Perception level } \\
\text { of SA }\end{array}$ & $\begin{array}{c}\text { Comprehension level } \\
\text { of SA }\end{array}$ & $\begin{array}{l}\text { Projection level } \\
\text { of SA }\end{array}$ \\
\hline $\begin{array}{l}\text { B. The tanks were engaged } \\
\text { in the armor- sweep } \\
\text { operations, }\end{array}$ & $\begin{array}{l}\text { 4. did you detect that } \\
\text { the enemy had been } \\
\text { eliminated when } \\
\text { seeing corpses all } \\
\text { over the battlefield? } \\
\text { What is your } \\
\text { perception based on? }\end{array}$ & $\begin{array}{l}\text { 5. would you judge } \\
\text { that the enemy might } \\
\text { pretend to be dead? } \\
\text { How do you } \\
\text { comprehend the } \\
\text { situation? }\end{array}$ & $\begin{array}{l}\text { 6. would you shoot the } \\
\text { corpses when seeing } \\
\text { them all over the } \\
\text { battlefield? What do } \\
\text { you project the } \\
\text { decision would result } \\
\text { in? }\end{array}$ \\
\hline $\begin{array}{l}\text { C. When an enemy in our } \\
\text { troop's uniform had been } \\
\text { captured and he } \\
\text { surrendered to us at once, }\end{array}$ & $\begin{array}{l}\text { 7. did you check his } \\
\text { identity as a prisoner } \\
\text { of war? What is your } \\
\text { perception based on? }\end{array}$ & $\begin{array}{l}\text { 8. would you judge } \\
\text { that he might pretend } \\
\text { to surrender? How do } \\
\text { you comprehend the } \\
\text { situation? }\end{array}$ & $\begin{array}{l}\text { 9. would you shoot } \\
\text { him? What do you } \\
\text { project the decision } \\
\text { would result in? }\end{array}$ \\
\hline $\begin{array}{l}\text { D. You were assigned to } \\
\text { pin down the enemy to } \\
\text { protect our logistics units. } \\
\text { But with only five tankers, } \\
\text { your only tank just broke } \\
\text { down in the middle of the } \\
\text { defile that the enemy was } \\
\text { going to pass through } \\
\text { soon. For the oncoming } \\
\text { around } 300 \text { enemies, }\end{array}$ & $\begin{array}{l}\text { 10. did you consider } \\
\text { that you have } \\
\text { enough time and } \\
\text { sources to prepare } \\
\text { for fighting? What is } \\
\text { your perception } \\
\text { based on? }\end{array}$ & $\begin{array}{l}\text { 11. would you judge } \\
\text { that you can complete } \\
\text { the mission? How do } \\
\text { you comprehend the } \\
\text { situation? }\end{array}$ & $\begin{array}{l}\text { 12. would you face it } \\
\text { head-on and fight } \\
\text { against them? What } \\
\text { do you project the } \\
\text { decision would result } \\
\text { in? }\end{array}$ \\
\hline
\end{tabular}

Bloom's taxonomy serves as the evaluation criterion for the cadets' learning performance of SA. In the aspect of perception, whether the cadets attained the level of knowledge would be observed. Then for comprehension, their performance at the levels of comprehension, analysis, and synthesis would be evaluated. Finally, in the dimension of projection, the researchers would identify the cadets' achievement at the levels of application and evaluation. In each situation, there are three questions regarding Endsley's three steps respectively. Therefore, the worksheet includes twelve questions: Situation A (questions 1 3), Situation B (questions 4-6), Situation C (questions 7-9), and Situation D (questions 10 12). In each question, there is a yes-or-no question, then the reasons of the judgement should be given. From the reasons, the researchers try to evaluate if the participants' SA operation reach Bloom's cognitive objectives.

Then, each group plays one scene regarding the situation whether to kill the people in the battlefield. Situated in the combat rather than in the textbook, the cadets have to decide if they would take the same plot in the film or create a new one to show a different SA operation. Finally, concept maps are used to evaluate whether the cadets build a more complete concept of SA. As Cañas and Novak (2009) claimed, concept maps organize and represent knowledge 
by graphical tools. They explained that concepts are understood as a recognized consistency, style in objects or events, or records in objects or events, which are nominated by a label. One or more words are used to illustrate the label. To be more concise, concepts are expressed in different shapes such as squares, rectangles, circles or others. Then connecting lines are used to link and clarify the relationship between concepts through words or phrases given on the lines. A map is thus formed. Since new nodes on the map represent newly acquired concepts of SA, the cadets did concept mapping twice with coggle on the web before and after the course.

\section{FINDINGS}

With SL instruction, this paper investigates how the cadets' performance of SA changes according to Bloom's taxonomy of cognitive learning objectives by means of worksheets, English role-plays, and concept maps.

\subsection{SA Performance on Worksheets}

The researchers took an in-depth qualitative analysis on what and how the cadets reacted to the SA in the four situations concerning killing people in the battlefield.

\subsubsection{Situation A about killing the scout}

Among 16 participants, 11 cadets perceived that German kids were forced to join up in the pre-worksheet. It means that most of the cadets had the historical background knowledge, so 9 cadets comprehended the kid as an enemy and would shoot him without hesitation. But among 7 cadets not wanting to kill the kid, cadets D, F, and $\mathrm{H}$ stated that the policy of forcing kids to fight is against humanism; even they perceived the severe situation, they would not shoot and predicted that they were able to capture him alive. In the post-worksheet, after watching that German kids and women were hung because they refused to join the army, one more cadet perceived the difficult situation. When seeing the lieutenant shot and burnt to death, 12 cadets comprehended the menace and decided to shoot the scout. Four cadets still would hesitate to shoot because he was an untrained soldier. For those chose to shoot, they projected the act could protect their army from a sneak attack. Cadet M said: "On the battlefield, either you (the enemy) or I have to die", so the approvers considered that whoever would harm the army should be killed. On the contrary, for those chose not to shoot, they projected that a fight on foot might capture the scout before he/she took action. Cadet $\mathrm{O}$ thought further that by interrogating him, they might locate the other kids and avoid such difficult choice again.

\subsubsection{Situation B about killing the corpses}

To compare the pre- and post-worksheet, more and more cadets (from 10 to 13) detected that the enemy had been eliminated since they did not see the danger of the dead bodies. And 
fewer and fewer cadets (from 13 to 8) comprehended that the enemies might pretend to be dead and would shoot the corpses (from 13 to 7) to ensure the dead bodies wouldn't stand up and shoot back. According to cadet H, Norman's breaking down under the pressure of killing dead bodies would demoralize the tankers. As cadet $\mathrm{C}$ projected, shooting the corpses might kill the comrades owing to the irregular formation of the allied forces. That is why the half cadets, who were aware of the menace of fake corpses, stayed unwilling to shoot the corpses. The abstract concepts such as sense of morality regarding respect to the corpses and camaraderie to avoid killing the injured allied forces, serving as threads to decide their tactic, make them stay inactive to the menace of being attacked by the fake corpses.

\subsubsection{Situation C about killing the prisoner of war}

In the pre-worksheet, half the cadets did not check if the German soldier was a POW since they did not perceive the difference between a captured enemy and a POW, and did not know how to treat POWs. Twelve cadets would judge that he might pretend to surrender, thus, they would shoot him. They projected that not shooting him and taking him along with the troop meant to carry a walking bomb. Cadet F screamed that the bomb would explode any time. In the post-worksheet, the result converses. In the film, the German soldier with only a family photo was not armed, so the cadets considered that even he pretended to surrender or became a Soldier in AWOL (Absent WithOut Leave), he was harmless. The probability of fake surrender was excluded. In addition, after the teachers' introduction of LOAC, the cadets learned that killing the POW transgressed Geneva Conventions and that they would be brought to the Hague tribunal after the war. Cadet $\mathrm{O}$ explained that only when people respected and followed the International humanitarian law can they really fight for righteousness and peace. Cadet P claimed that the POW should be sent to the POW camp; he quoted from the teachers' instruction in International Humanitarian Law that those who are outside of combat shall be protected against acts of violence. But 5 cadets would still shoot the German because they would not risk being betrayed and revealing their intelligence. Cadet $\mathrm{F}$ borrowed a Chinese old saying: "I would rather mistakenly kill one hundred people than mistakenly release one person."

\subsubsection{Situation D about fighting against heavy odds}

In pre-worksheet, 11 cadets perceived that the impaired tank could not be fixed in a short time, and comprehended that they could not win the overwhelming number of enemies. Cadet A predicted that to fight with them was just like "throwing a straw against the wind". The other 5 cadets still wanted to have a try because they possessed a deep sense of honor. 
Cadet $\mathrm{N}$ also claimed that warriors had to go out on a limb; cadet $\mathrm{M}$ agreed with him to sacrifice for the fatherland and to complete their mission at any price. But in the post-worksheet, the cadets' SA changes. Eleven cadets were touched by the plot in which the tankers wholeheartedly cooperated with each other, so the number of the cadets who considered that they would have enough time and sources to prepare for fighting against heavy odds increased from 5 to 11 . This big conversion is due to their trust in the crew members' loyalty to the tank commander. Cadet J, K, and L noted that they would not leave a comrade behind and would have good analysis over the environment and tactics for battling. Additionally, since the teachers had explained the heavy blow that the Allies would have suffered if the logistics units had not been well protected, the cadets predicted that the decision to battle might help the Allies win the final victory. Cadet $\mathrm{O}$ and $\mathrm{P}$ chose to hide themselves first and find some other ways to fight back; they projected they could also complete the mission.

\subsection{SA Operation in English Role Plays}

The topic each group chose to give a role-play is the same with the one that they did the vocabulary presentation in the previous classes; they are more familiar with the content. Group A adopted the same plot assigned to them because the teammates evaluated the SA operation correct in situation A. Generally, people did not know about kids' being armed, so they would easily ignore the threat. But Wardaddy predicted the danger and rapidly killed all the kid scouts to prevent the troop from more damages. In this respect, the group understood Norman's consideration and weakness, they copied the plot, then followed Wardaddy's quick decision, and solved the crisis. Nevertheless, they were expected to create another tactic to avoid shooting the kid scouts and prevent the death of the American lieutenant at the same time.

Group B also followed the original plot in situation B. According to the worksheets, the number of the cadets who agreed to kill the corpses decreased because the corpses did not really form menaces in the film. In the beginning, they thought of the possibility of feign death and wanted to show classmates the danger of not shooting the corpses; but owing to the limited English ability, this group could not adapt the plot and operate another SA consequently.

Group C employed a different SA to solve the conflict between Wardaddy and Norman in killing the POW or not. The cadets comprehended that they had to obey the rule of engagement, namely, to protect the POW against acts of violence, however, they projected the danger of keeping a POW with them, so they planned to send him to the camp of POWs. Thus, according to their new plot, Wardaddy was convinced to allow the prisoner to go with the troop, 
but the prisoner secretly wrote their following moving track on the back of his family picture and asked the German army to push all women and kids to join fighting as the allied forces were powerful. This caused many women and kids to be hung because they refused to join. After the German officer, who ordered to hang German women and kids, was shot, the prisoner's family picture was found in his hand. To the American troop's surprise, the POW had betrayed them before reaching the camp. Thus, the prisoner was shot by Norman, who regretted and became furious about the German army's cruel demand. Norman's reluctance to shoot the prisoner proved to be fatal. Comparing the law with the army's safety, Wardaddy's response is: "The law is for the peace, the reason is for the war." Under this situation, the new SA failed because the cadets only comprehended the importance of not violating the law but not the method of controlling the POW's action. At the level of comprehension, the American troop did not take away anything available for revealing the American troop's secret from the POW. Additionally, their expectation of sending the POW to the tribunal did not come true; he was still killed by Norman on the spot. What's more, besides the POW, the German kids and women were hung because of the event. Therefore, there is an error in the cadet's comprehension, so accordingly they made a wrong decision and perform a wrong action.

Group D changed the tactic of guarding the crossroad to protect the American logistics units from the enemy's attack. Having the insight that it is hard to fight against a battalion with only five tankers and a busted tank, the cadets had a new plot: Wardaddy and Grady hid in the forest line first, after the marching battalion passed, they tried to stay and play scouts, fix the tank, and dissemble the radio for passing the message to the base of the allied forces, where Bible, Boyd, and Norman (who used to be a typist and knew how to use a transmitter) would run to and ask for help from the air force. The air strike successfully destroyed the enemy, and Wardaddy said: "It's time to fix our home (the tank), I hope it really helps us defeat the Krauts and we are free to go back our real homes."

\subsection{SA Performance in Concept Maps}

Concept maps are used to analyze whether the cadets developed new or different SA concepts. One knot is treated as one point, the number of new nodes signifies the number of newly acquired concepts. On average, 11 knots increased in the post-test (see Table 2). 
Table 2. Number of Knots on the Cadets' SA Concept Maps

\begin{tabular}{lll}
\hline & Number of Knots & Mean \\
\hline Pre-test & 166 & 10.38 \\
Post-test & 334 & 20.94 \\
\hline
\end{tabular}

\subsubsection{Pre-concept map}

Information about SA in the military of Taiwan maintained limited although the term is said to frequent human factor scientists of the US Air Force after the Korean War and Vietnam War (Watts, 2004). Accordingly, the concept of SA is relatively new to the cadets; they have to memorize the three stages of SA, then integrate the military knowledge previously acquired, and finally come up with a concept map. For cadet A, he used military English terms to express a rough idea about "situation" "awareness" literally. However, many terms were repeated and the knots of concept were almost duplicate (see Figure 3). As to cadet B, the context of the concept map was similar to the divisions of responsibilities in the Ministry of National Defense (MND) of Taiwan: human resources, intelligence, combat and planning (missing here), logistics, as well as communication (see Figure 4).

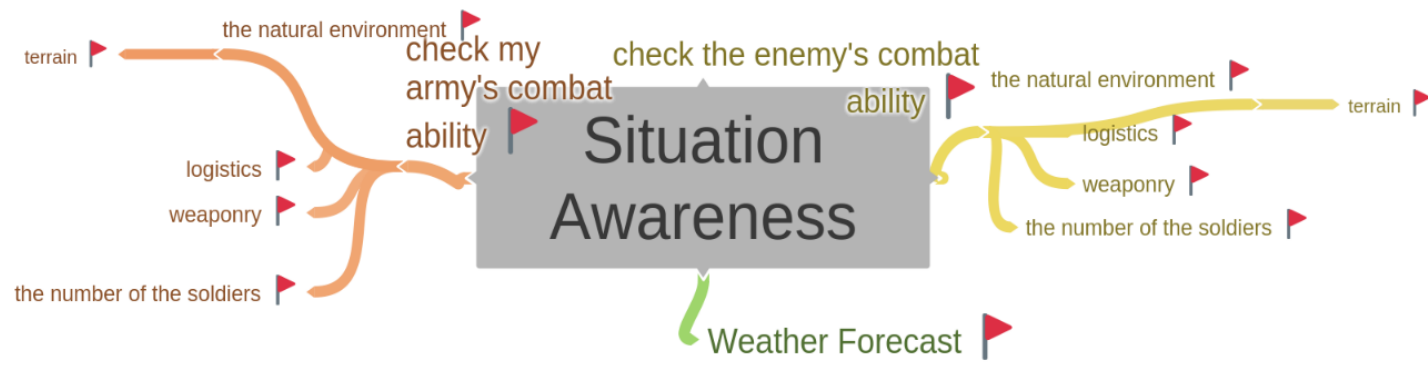

Figure 3 Pre-concept Map of Cadet A

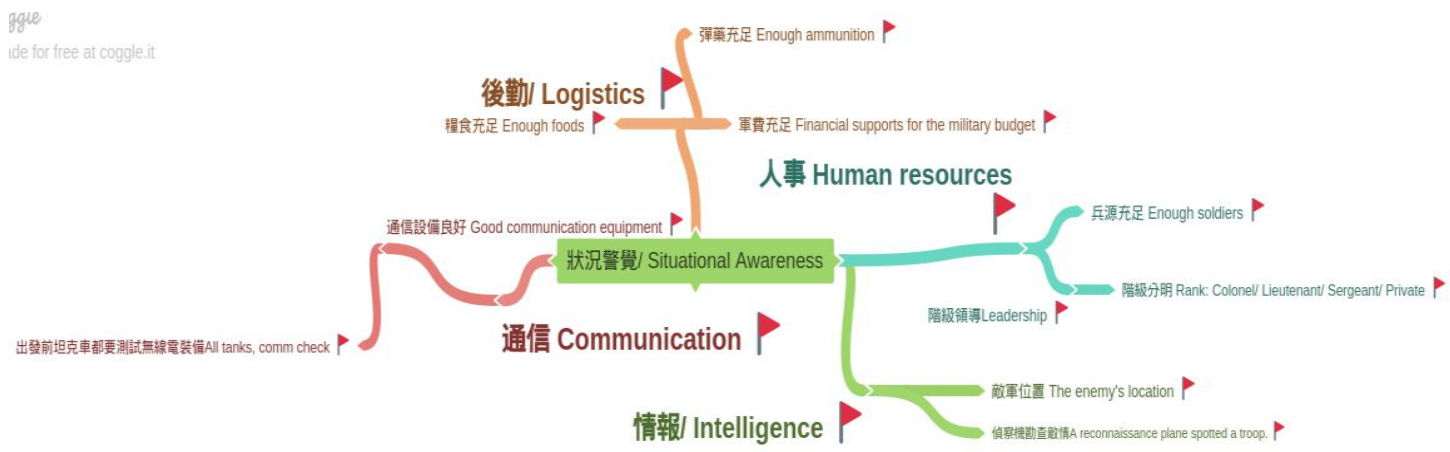

Figure 4 Pre-concept Map of Cadet B

\subsubsection{Post-concept map}

After the teaching activities, many cadets were more familiar with the important factors of SA such as attention, intelligence, logistics, vigilance, compatibility and fatigue. Using Endsley's theory of SA, they considered more military measures. On cadet A's post-concept map, varied military actions based on Endsley's theory were shown through well-organized 
contingencies of war in different colors. Besides, as his English proficiency was better than others, the cadet used more advanced vocabulary to articulate his idea such as adversaries, deployment, ration, capital, friends \& foes and allies by WebQuest or referring to the worksheets (see Figure 5). In cadet B's case, his concept map was continually associated with his prerequisite knowledge about the MND departments: human resources, intelligence, combat and planning (missing here), logistics, as well as communication. Meanwhile, he combined the key elements of The Art of War and the ME terms in this film to convey his SA views (see Figure 6).

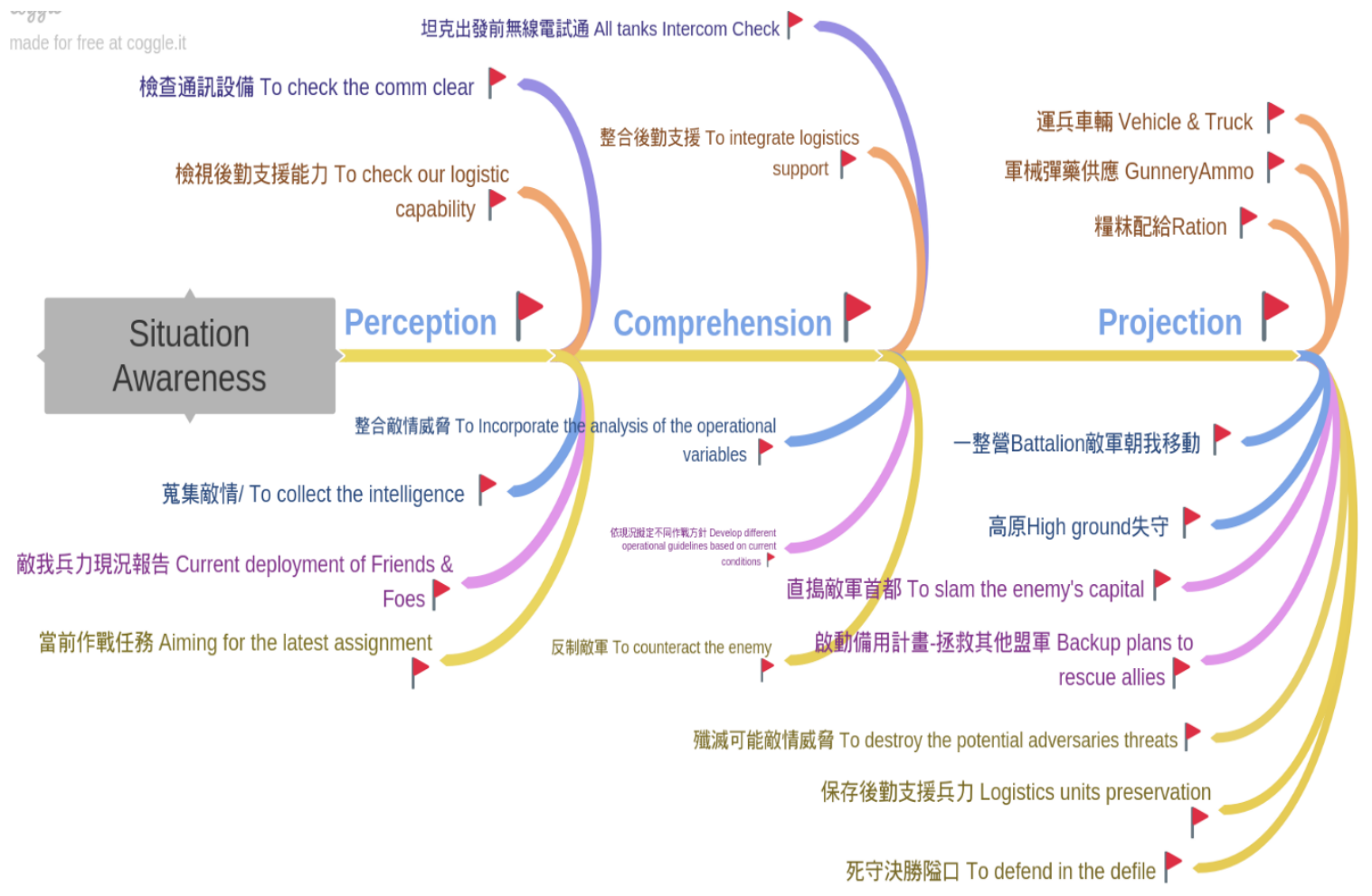

Figure 5 Post-concept Map of Cadet A 


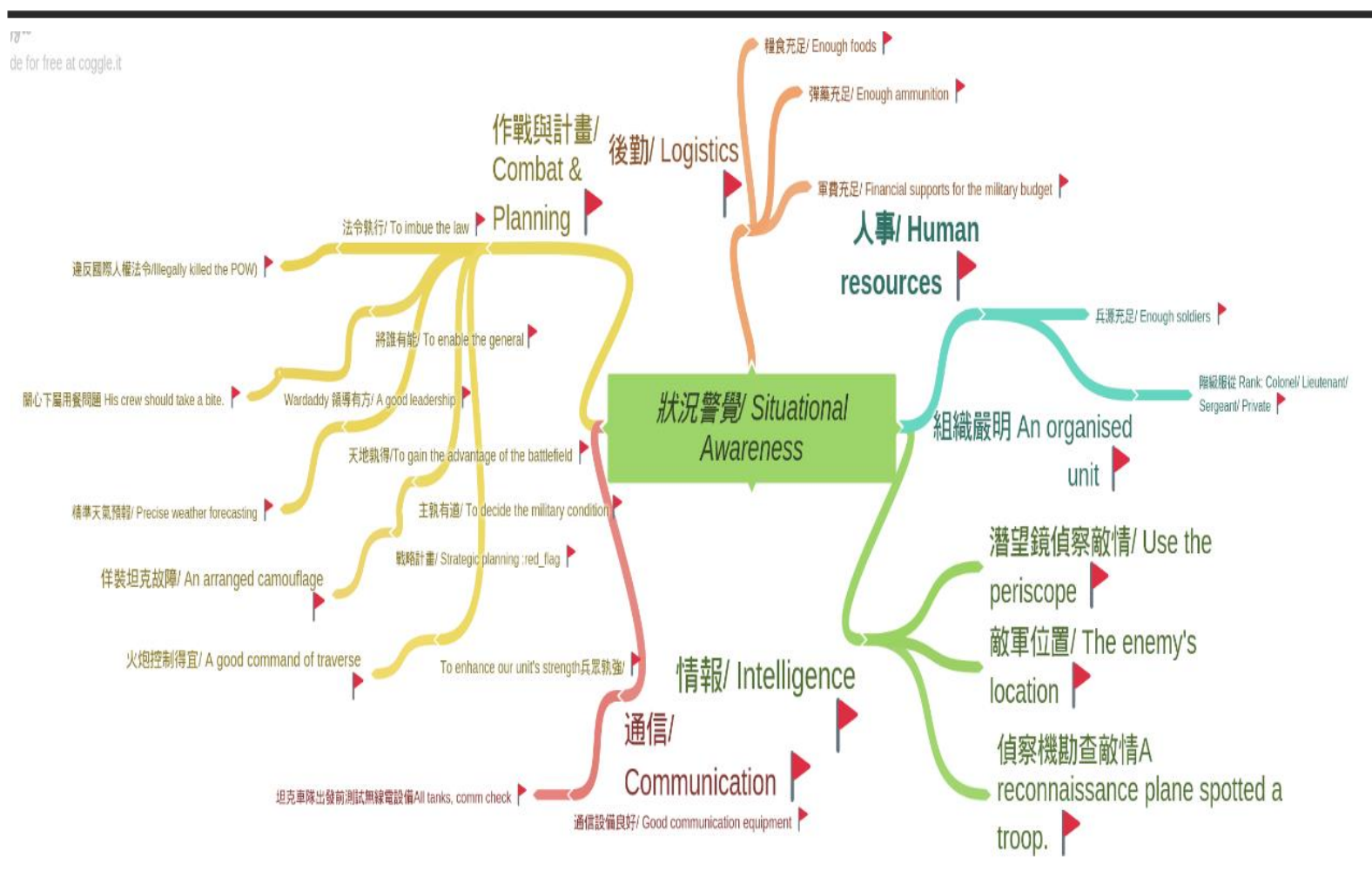

Figure 6 Post-concept Map of Cadet B

\section{DISCUSSION}

As Fenwick (2001) indicated, situative perspectives emphasize the connection between individuals and their communities of practice in a collective explanation of experiential learning; so the cultural context, the communities' experience sharing, and the educator's management of or intervention in the learning influence the practitioners' knowledge construction. The worksheet results were extremely affected by four factors: the film, the teachers' introduction of the laws, the cadets' previous learning in other military courses, and their sense of honor in being a future officer. Their answers are based upon humanitarian, tactical, and personal considerations. The participants did not tend to treat the German scout as a threatening soldier, but their SA enhances because of the film plot, in which the German scout really endangers the army. On the contrary, in situation two and three, their strong SA reduces owing to the worry about committing demoralization and a crime of killing a POW. By the same token, the cadets supposed that to fight against heavy odds was destined to fail in the pre-test, but after seeing the film, they were confident of beating the huge number of German soldiers in the post-test by using a different tactic.

For the English role play on SA operation, most of the cadets have learnt the steps of running SA when thinking of the two sides of the same decision. The SA operation result in the English role play, adopted to judge whether the SA solved crises, is shown in Table 3. According to Jones \& Endsley (1996), level 2 SA errors occurred due to diverse reasons such 
as a lacking or incomplete mental model as well as over-depended default values. Group C's operation of SA became problematic because they expected to obey the rule of engagement but ignored real-time data of the POW's betrayal. It could be treated as a teaching material to demonstrate that an error in any SA levels would result in bad decision and action. Although one group makes an error in projecting the result of releasing the POW, they choose to do the right thing first by following the Law of Armed Conflict. After finding the betrayal of the POW, they evaluate and project the situation again and choose to do things right by killing him. Thus, in the aspect of crisis solvation, three groups succeeded. The result showed that most of the cadets appeared enlightened by the steps of running SA, and tried hard to think of the two sides of the same decision before making one.

Table 3. The SA Operation Result

\begin{tabular}{lcc}
\hline Group & $\begin{array}{l}\text { Whether an error } \\
\text { occurred in the SA }\end{array}$ & $\begin{array}{l}\text { Whether the SA solved } \\
\text { crises }\end{array}$ \\
\hline A. Killing the boy scout & $\mathrm{X}$ & $\mathrm{V}$ \\
$\begin{array}{l}\text { B. Killing the corpses } \\
\text { C. Killing the POW }\end{array}$ & $\mathrm{X}$ & $\mathrm{V}$ \\
$\begin{array}{l}\text { D. Fighting against the heavy } \\
\text { odds }\end{array}$ & $\mathrm{V}$ & $\mathrm{X}$ \\
\hline
\end{tabular}

In the aspect of concept mapping, by virtue of the intensive discussion about SA, the instruction in Endsley's theory of SA, the review of the post-worksheets, and the argument over the modified plots in the role play, the cadets obtained the knowledge and constructed a whole picture of SA. On account of the specialized training program in the military academy, many cadets are internship cadres. They took military courses, which they now correlated to SA learning in this class. Thus, they produced new SA concepts, which were a double of those in the pre-test, revealing their full engagement in and great achievement of SA concept mapping. Wu et al., (2012) claimed that concept maps showed the association of students' internal semantic networks to the knowledge they perceive, accumulate, and comprehend. From the post-concept maps, the cadets exactly combined the former perception of the MND departments, the knowledge accumulated from other military courses, and the comprehension of Endsley's theory and the SA operation in the film.

As situated learning instruction for military English has not yet been implemented, the present study is significant in gaining a positive research result in SA learning. The design of an SL environment in a ME course allows the cadets to learn SA in practice, which would solve the cadets' difficulties in gaining high achievement in ME. 


\section{CONCLUSION}

Using a film as an authentic military context, this paper makes an in-depth qualitative analysis of SL instruction in SA for ME course. The worksheet result on SA reveals that the cadets have learnt to operate SA by following Endsley's theory--perceiving, comprehending and projecting situations. To match with Bloom's cognitive levels, the cadets perceive the present situation through "apprenticeship" by collecting and gaining the relevant knowledge. Then, they comprehend the situation by applying the teachers' instruction, the character's experience, and the peer's discussion. They also analyze the appropriateness of SA in the film by referring to the relevant laws and the former lessons from other military courses. Finally, they synthesize and evaluate another operation they project as harmless to both the troop and the enemies with special identification.

Subsequently in the English role play on SA operation, the cadets learn in practice when they perceive and comprehend the situations by going through Bloom's first five levels of cognition. All the cadets achieve the highest level of cognition-evaluation-by comparing the factors of the information and appraising their accuracy and benefits (Birlik, 2015) and a half of the cadets create different results of SA operation. Although in the aspect of crisis solvation, not all groups succeed, the cadets have developed critical thinking. Bloom's evaluation copes with Endsley's step of prediction even if the first evaluation may result in danger; the method of crisis intervention is re-evaluated. Using the ME terms learnt before, they deliver the dialogues fluently, two groups have advanced ability to create their own dialogues.

Third, the concept maps lay bare their significant achievement in both acquiring the knowledge and constructing a quite complete picture of SA. They are a synthesis of the course activities, the military knowledge previously acquired, the idea inspired by the structure of the MND departments of Taiwan (i.e. human resources, intelligence, combat and planning, logistics, as well as communication), as well as Endsley's theory of SA embedded in the film.

As a whole, by worksheets and concept maps, the cadets learn the concept of Endsley's SA. By role plays, they learn the operation of Endsley's SA. And by the SL instruction in SA, they achieve Bloom's taxonomy of cognitive learning objectives in SA learning. Through an in-depth qualitative analysis, the researchers found that an SL instruction improves the cadets' learning performance of SA. 


\section{REFERENCES}

Barr, S., Ferro, A., \& Prion, S. (2019). An innovative academic-practice partnership to enhance the development and training of military nurses. Journal of Professional Nursing, 35(5), 369-378. https://doi.org/https://doi.org/10.1016/j.profnurs.2019.04.008

Bloom, B. S. (1956). Taxonomy of educational objectives: The classification of educational goals. Cognitive Domain.

Brown, J. S., Collins, A., \& Duguid, P. (1989). Situated cognition and the culture of learning. Educational Researcher, 18(1), 32-42. https://doi.org/https://doi.org/10.2307/1176008

Catalano, A. (2015). The effect of a situated learning environment in a distance education information literacy course. The Journal of Academic Librarianship, 41(5), 653-659. https://doi.org/https://doi.org/10.1016/j.acalib.2015.06.008, 2015

Comas-Quinn, A., Mardomingo, R., \& Valentine, C. (2009). Mobile blogs in language learning: Making the most of informal and situated learning opportunities. ReCALL, 21(1), 96-112. https://doi.org/https://doi.org/10.1017/S0958344009000032

Contu, A., \& Willmott, H. (2003). Re-embedding situatedness: The importance of power relations in learning theory. Organization Science, 14(3), 283-296. https://doi.org/https://doi.org/10.1287/orsc.14.3.283.15167

Efe, H., Demiröz, H., \& Akdemir, A. S. (2011). A situated learning practice for language teaching classes: Teaching spoken English with authentic sketches. Sino-US English Teaching, 8(9), 549-555.

Endsley, M. R. (1988). Design and Evaluation for Situation Awareness Enhancement. Proceedings of the Human Factors Society Annual Meeting, 32(2), 97-101. https://doi.org/10.1177/154193128803200221

Endsley, M. R. (2001). Designing for situation awareness in complex systems. Proceedings of the Second International Workshop on Symbiosis of Humans, Artifacts and Environment, 1-14.

Fenwick, T. J. (2001). Experiential Learning: A Theoretical Critique from Five Perspectives. Information Series No. 385.

Greeno, M. (1993). Smith." Transfer of Situated Learning," Transfer on Trial., Detterman and Sternberg, eds. Ablex Publishing. NJ.

Huang, K., Lubin, I. A., \& Ge, X. (2011). Situated learning in an educational technology course for pre-service teachers. Teaching and Teacher Education, 27(8), 1200-1212. https://doi.org/10.1016/j.tate.2011.06.006

Jones, D. G., \& Endsley, M. R. (1996). Sources of situation awareness errors in aviation. Aviation, Space, and Environmental Medicine.

Kyratzis, A., \& Johnson, S. J. (2017). Multimodal and multilingual resources in children's framing of situated learning activities: An introduction. Linguistics and Education, 41, 1-6. https://doi.org/10.1016/j.linged.2017.07.002

Lave, J., \& Wenger, E. (1991). Situated learning: Legitimate peripheral participation. Cambridge university press. http://dx.doi.org/10.1017/CBO9780511815355

Matsuo, M., \& Tsukube, T. (2020). A review on cognitive apprenticeship in educational research: Application for management education. The International Journal of Management Education, 18(3), 100417. https://doi.org/https://doi.org/10.1016/j.ijme.2020.100417

Shih, Y.-C., \& Yang, M.-T. (2008). A Collaborative Virtual Environment for Situated Language Learning Using VEC3D. Journal of Educational Technology \& Society, 11(1), 56-68. http://www.jstor.org/stable/jeductechsoci.11.1.56

Utley, B. L. (2006). Effects of Situated Learning on Knowledge Gain of Instructional Strategies by Students in a Graduate Level Course. Teacher Education and Special Education, 29(1), 69-82. https://doi.org/10.1177/088840640602900108 
Uz Bilgin, Ç. (2016). Facilitating English as a foreign language learners' vocabulary learning, task completion and contextual vocabulary exploration processes in a mobile supported situated learning environment. Middle East Technical University.

Wang, R., Lowe, R., Newton, S., \& Kocaturk, T. (2020). Task complexity and learning styles in situated virtual learning environments for construction higher education. Automation in Construction, 113, 103148. https://doi.org/https://doi.org/10.1016/j.autcon.2020.103148

Watts, B. D. (2004). Clausewitzian friction and future war (Issue 68). Institute for National Strategic Studies, National Defense University.

Wenger, E. (1999). Communities of practice: Learning, meaning, and identity. Cambridge university press.

WePengiran, B., Norainna, P. H. S., \& Besar, H. (2018). Situated Learning Theory: The Key to Effective Classroom Teaching? HONAI, 1(1). https://doi.org/https://doi.org/10.2121/.v1i1.1022

Wu, P.-H., Hwang, G.-J., Milrad, M., Ke, H.-R., \& Huang, Y.-M. (2012). An innovative concept map approach for improving students' learning performance with an instant feedback mechanism. British Journal of Educational Technology, 43(2), 217-232. https://doi.org/https://doi.org/10.1111/j.1467-8535.2010.01167.x

Yang, Y.-F. (2011). Engaging students in an online situated language learning environment. Computer Assisted Language Learning, 24(2), 181-198.

https://doi.org/10.1080/09588221.2010.538700 